\title{
ПРОБЛЕМА ДИТЯЧИХ СТРАХІВ У ДОСЛІДЖЕННЯХ ВІТЧИЗНЯНИХ ТА ЗАРУБІЖНИХ НАУКОВЦІВ
}

УДК: 159.09 .07

\section{Камінсъка Ольга Володимирівна \\ Доктор психологічних наук, дочент, професор ка- федри загальної психологї та психодіагностики, Рівненський державний гуманітарний університет, м. Рівне (Украӥна)}

\section{Громик Наталія Василівна}

Магістрант, Рівненський державний гуманітарний університет, м. Рівне (Украӥна)

\begin{abstract}
Анотація. У статті здійснюється теоретичний аналіз поняття «страх», визначається його сутність з точки зору різних психологічних течій. Наведено погляди вітчизняних та зарубіжних вчених щуодо проблеми страху. Приведені думки науковців з приводу розмежування понять «страх» та «тривога». Визначено місие поняття «страх» в системі психологічних категорій. Проаналізовано особливості виникнення страхів в дітей дошкільного віку. Визначено переважаючі види дитячих страхів та умови переходу страхів у фобії. Показано вплив найближчого оточення дитини на виникнення в неї нав'язливих страхів. Вказано засоби та форми корекції страхів в дітей дошкільного віку. Проаналізовано роль механізмів психологічного захисту у нівелюванні дитиною власних страхів. Підкреслено необхідність надання психологічної допомоги дітям, в яких спостерігаються нав 'язливі страхи та фобії.
\end{abstract}

Ключові слова: страх, фобія, тривожність, емоції, дошкільний вік.

Постановка проблеми. Актуальність дослідження проблеми страху обумовлена його значною роллю у житті дитини. Страх може бути присутній як на рівні свідомості, так і на рівні підсвідомості особистості, впливаючи на різні сфери іiі життя. Страх, який функціонує на рівні фобії, здатен значною мірою знижувати якість життя особистості, обмежуючи ऑiі життєдіяльність, соціальну взає- модію та негативно впливати на процес соціалізації, який є особливо важливим у дошкільному віці. Відповідно, актуалізація страху, його нав'язливий характер, порушує процес становлення особистості дитини, призводить до деструктивних змін у іiї взаємодії з дорослими, однолітками або ж зумовлює викривлене сприйняття предметного середовища, залежно від об'єкту, на який спрямоване почуття 
страху. Враховуючи це, розуміння природи страху, детермінант та механізмів, які зумовлюють його актуалізацію та значну емоційну насиченість, дозволяє виробити ефективні підходи щодо його профілактики та корекції в дітей дошкільного віку, а також визначити стратегії надання психологічного супроводу родині, в якій виховується дитина, що страждає від яскраво виражених страхів.

Аналіз останніх досліджень та публікацій. Проблема дитячих страхів становить великий інтерес для психологічної науки, а іiі експериментальна розробка набуває все більшого значення у сучасній практичній діяльності фахівців.

Досліджено особливості появи страхів в дітей різного віку. Зокрема I. Бабарикіна [1] аналізувала особливості вікової динаміки страху, розглядаючи його як негативний емоційний стан, що відображає у свідомості конкретну загрозу для психологічного благополуччя людини, і який проявляється у прогнозуванні та передчутті невдачі під час виконання певних дій. Появу страхів дослідниця пов'язувала зі специфікою емоційного досвіду дитини. В дітей зі стереотипним емоційним досвідом домінує страх ситуації перевірки знань, а серед учнів 3 нестереотипним емоційним досвідом переважає страх соціального неприйняття і покарання. Також було визначено зниження від молодшого шкільного до підліткового віку показника страху ситуації перевірки знань, страху осоромитися перед однокласни- ками, страху почути насмішки однокласників, страху запізнитися на урок, страху покарання за погану поведінку, страху виклику до директора школи та страху, що ніхто не захоче дружити $з$ учнем. Від молодшого шкільного до підліткового віку підвищилися показники страху публічної перевірки знань.

С. Томчук досліджував генезу негативних психічних станів, приділяючи особливу увагу появі в дітей страхів. Детермінантами появи та розвитку негативних психічних станів у молодших школярів він вважає індивідуально-типологічні особливості нервової системи та властивості темпераменту. Серед низки соціальних чинників появи страхів виділяються умови виховання дітей у сім'ї і в школі. Найбільш сильно детермінують появу деструктивних станів у дітей такі стилі батьківського ставлення, як гіперсоціалізація, відторгнення, симбіоз. Значно більше дітей з негативними станами у неблагополучних (неповних, конфліктних тощо) сім'ях. На генезу негативних станів у школі впливає особистість учителя, а саме його педагогічний стиль, особливо у випадку, коли він зорієнтований на результат діяльності, а не на розвиток учнів [15].

О. Макух відносить страхи до межових психічних станів та стверджує, що їх підгрунтям виступають слабкі, стерті форми нервовопсихічних розладів, що перебувають на межі психічного здоров'я та вираженої патології і у випадку частих психотравмуючих ситуацій - призводять до дисгармонійного розвитку 
особистості. При цьому передумовами появи межових психічних станів є: 3 одного боку, ряд соціально-психологічних чинників, пов'язаних $з$ особливостями навчання та ситуаціями сімейного виховання, а з іншого - психічні травми, вікові особливості, а також нервовосоматичні порушення. Розвиток у дітей межових психічних станів значною мірою спричиняється невротичним реагуванням батьків на певні обставини соціального життя сім'ї. Додатковий вплив мають обставини шкільного життя та особистість учителя із порушеним педагогічним стилем організації навчального процесу. 3 часом ці стани позначаються на розумовій активності, мисленнєвих діях школяра та ведуть до низької навчальної успішності [10].

Особливості прояву страху на рівні фобії досліджувала Л. Стукан, яка особливу увагу приділяла вивченню соціальних фобій. Нею виділено три типи субклінічних проявів соціальної фобії: страх інтерперсональної взаємодії, страх представлення на людях та змішаний тип. При страхові інтерперсональної взаємодії домінують тривожні, педантичні та дистимні риси характеру, при страху представлення на людях переважають тривожні, збудливі та екзальтовані риси характеру. При невротичних фобічних розладах 3 домінуванням соціально-обумовлених страхів інтерперсональної взаємодії виявляються астено-фобічний та депресивно-фобічний симптомокомплекси. За наявності соціальної фобії із страхом пред- ставлення на людях - антено-вегетативний та тривожно-фобічний симптомокомплекси, при змішаному типі - депресивно-фобічний та тривожно-фобічний симптомокомплекси [14].

Також дослідниця встановила, що до розвитку соціальних фобій призводить негативний вплив чинників соціогенного, психогенного, соціально-психологічного та індивідуально-психологічного змісту. 3 виділених груп факторів ризику виникнення соціальної фобії максимальну питому вагу мають індивідуально-психологічні фактори. Визначальними у розвитку соціальної фобії є такі характеристики, як сором'язливість, відчуженість, мовчазність, труднощі у спілкуванні, невпевненість у своїх силах, низька самооцінка, висока особистісна тривожність, вразливість, стурбованість, підвищений та високий рівень ситуаційної тривожності, напруженість, фрустрованість, емоційна нестійкість, ригідність [14].

Незважаючи на значну кількість розробок, що стосуються піднятої проблеми, недостатньо систематизованими залишаються уявлення про природу страху, місце цього поняття в системі інших психологічних категорій, детермінанти дитячих страхів. Зокрема, мало дослідженими залишаються чинники, що провокують появу страхів в дошкільному віці та недостатньо розробленими є стратегії їх профілактики та корекції.

Метою статті $\epsilon$ висвітлення особливостей проблеми страху у дослідженнях вітчизняних та зарубіжних науковців. 
Виклад основного матеріалу. Аспекти емоційних проявів особистості, що пов'язані 3 виникненням страхів у дітей, досліджували К. Ізард [5], 3. Фрейд [16], М. Кляйн [6], О. Захаров [4] та інші. Аналіз проблеми страхів у дітей дошкільного віку є особливо важливим, оскільки саме цей віковий період відрізняється ускладненням системи вимог до дитини, до їі рефлексивних здібностей та інших психічних якостей. Нова соціальна ситуація розвитку в цей період багато в чому стає стресовою, що зумовлює появу психічної напруженості у дошкільнят, що, в свою чергу, призводить до прояву можливих порушень розвитку. Страх є базовою емоцією людини та активізується одним 3 перших в ранньому дитинстві супроводжуючи iї в усі вікові періоди, виконуючи надзвичайно важливі соціальні та психологічні функції [11].

Страх - це емоція, яка виникає в ситуаціях загрози біологічному або соціальному існуванню індивіда і скеровує його на джерело справжньої або уявної небезпеки. У сучасних дослідженнях страх визначають як негативну емоцію, як стан, емоційне переживання та нестійке почуття [2, с. 426]. Це емоційна реакція на небезпеку, що виникає як умовний рефлекс, механізм саморегуляції організму людини в навколишньому середовищі. Психічний стан страху характеризуються тим, що дитина не керує свідомо своїми діями [2, c. 427].

Серед різних негативних психічних станів найбільшу групу складають негативні емоційні стани, оскільки цей компонент є домінуючим. Група емоційних психічних станів незалежно від їхньої модальності у дітей займає центральне положення та впливає на розвиток інших психічних станів. Розгляд основних детермінант появи та розвитку негативних психічних станів вказує на їх переважно соціально-психологічне походження (нова соціальна ситуація розвитку, поява нових та складних обов'язків, формування нової системи міжособистісних взаємовідносин) [15].

Можна розрізняти страхи за критеріями тривалості; частоти та інтенсивності переживання; за образним змістом (реальні чи фантастичні); за ступенем усвідомлення; за походженням (навіювані, особистісно обумовлені, ситуативні); дорослі та дитячі; первині та вторинні [4, с. 203].

М. Кляйн описала ще одну форму страxy: коли людина проектує власні агресивні потяги, вона починає боятися, що той, на кого була направлена ця проекція, стане для неї небезпечним. Схожу структуру мають усі параноїдальні страхи [6, с. 34]. Натомість О. Захаров поділяє страхи на природні - пов'язанні із загрозою для життя, внутрішні - не мають під собою реального підгрунтя та соціальні - боязнь змін соціального оточення чи статусу [4, с. 79]. У психоаналізі 3. Фрейда страх поділяється на два види: афективний стан очікування небезпеки і страх перед певним об'єктом [16, с. 106]. 
К. Ізард стверджує, що певні об'єкти, події чи ситуації мають тенденцію пробуджувати страх, тобто є природними сигналами небезпеки. У якості природних сигналів небезпеки він називає такі фактори: біль, самотність, раптова зміна ситуації, стрімке наближення об'єкта [5, с. 304].

Л. Стукан аналізувала такі види страхів: страх інтерперсональної взаємодії, страх представлення на людях, змішаний тип. Страх інтерперсональної взаємодії характеризується побоюванням виникнення нових, незвичних ситуацій. Тривожні побоювання концентруються на думках про власну соціальну неповноцінність, неспроможність проявляти активність при спілкуванні. Такий страх виникає при певному спектрі соціальних ситуацій, пов'язаних 3 необхідністю спілкування віч-навіч з іншими людьми. Високий рівень страху у таких дітей проявляється при спілкуванні 3 педагогами, незнайомими дорослими. Вони бояться висловити незгоду у спілкуванні з малознайомою людиною тощо. Такі особи найбільш комфортно почувають себе в звичних для них умовах (вдома, в колі родичів), в той час коли будь-яка обставина, яка виходить за ці межі, викликає у них появу тривоги. Прояви страху представлення на людях супроводжуються тривожними побоюваннями, які виникають при необхідності публічної демонстрації своїх знань та умінь. Такі діти бояться стати об'єктом підвищеної уваги з боку оточуючих, тим самим створивши негативне вра- ження про себе, бояться осоромитись. Вони намагаються виконувати захисні переборюючи дії, оскільки уникнути таких ситуацій часто було неможливим, і як наслідок, тривожний стан у них супроводжувався вираженим вегетативним компонентом. Характерним для страху представлення на людях є зв'язок тривоги $з$ певними визначеними ситуаціями. Провокують виникнення страху ситуації публічного виступу; тестування на визначення вмінь, здібностей, знань; перебування в центрі підвищеної уваги з боку оточуючих. Змішаний тип страху характеризується дискомфортом при спілкуванні з однолітками, педагогами, незнайомими людьми в поєднанні із страхом перевірки знань та вмінь, виступів перед багатьма людьми. Як правило, відчуття сильного страху завжди супроводжується проявами дисбалансу регуляторного впливу з боку вегетативної нервової системи у вигляді сильного серцебиття, тремору кінцівок, сухості у роті, відчуття холоду в кінцівках тощо [14].

В осіб зі страхом інтерперсональної взаємодії спостерігається зниження працездатності, фізична та психічна втомлюваність, емоційна лабільність, дратівливість, порушення сну, сновидіння негативного змісту, головний біль без чіткої локалізації, конфліктність, підвищена збудливість, нестриманість. В ситуаціях інтерперсональної взаємодії у дітей виявляються виражені вегетативні прояви у вигляді сильного серцебиття, тремтіння рук, головного болю. При наявності страху пред- 
ставлення на людях діти використовують захисні дії з метою зниження рівня тривоги, оскільки уникнути ситуації цього типу часто неможливо. Відчуття страху, яке виникає в ситуаціях представлення на людях, супроводжується вираженими вегетативними проявами у вигляді посиленого серцебиття, тремтіння рук, почервоніння обличчя, відчуття нестачі повітря, головного болю, відчуття «клубка» у горлі. Для таких дітей характерна підвищена фізична та психічна втомлюваність, слабкість, швидка виснажливість, погіршення концентрації уваги, головний біль, больові відчуття в серці та абдомінальних відділах, нудота, нестача повітря при хвилюванні, сонливість вдень та труднощі засинання увечері тощо. При змішаному типі страху спостерігаються виражені реакції уникнення та явища соціальної дезадаптації. Характерний пригнічений настрій, небажання спілкуватись 3 оточуючими, емоційна нестабільність [14].

Виникнення страхів безпосередньо пов'язане з рівнем тривожності дитини. Проблема тривоги і страху з психологічної точки зору підлягала спеціальному аналізу у дослідженнях 3. Фрейда [16, с. 226]. Він одним із перших розглядав спільно страх і тривогу та поєднав їх в одне поняття афекту. Афект - короткочасне, бурхливе переживання людини (гнів, лють, жах, відчай, раптова радість), що виникає, як правило, у відповідь на сильний подразник. У цьому стані знижується здатність людини осмислювати значення своїх дій і керувати ними [2, с. 23].

Тривога - негативно забарвлена емоція, що виражає відчуття невизначеності, очікування негативних подій, передчуття. На відміну від страху, причини тривоги зазвичай не усвідомлюються, але вона попереджає участь людини в потенційно небезпечних ситуаціях [2, с. 449].

Тривога є базовим станом для розгортання інших негативних психічних станів. Тривога в залежності від вроджених, індивідуально-типологічних чинників, особливостей досвіду емоційного реагування та психогенних ситуацій, може трансформуватись в дітей у такі негативні стани як страх, гнів, агресія, астенія, депресія (субдепресія) тощо [15].

М. Литвак наголошує на різниці між тривогою та страхом. Тривога - це реакція на реальну загрозу, а страх - стан неприємного передчуття, що виникає без видимої причини [8, с. 182]. Автор пропонує розглядати тривогу як емоцію, яка виникає при оцінці ситуації як несприятливої. Якщо ліквідувати джерело тривоги не вдається, то вона переходить у страх. На його думку страх - це результат тривоги та мислення.

Як страхи, так і тривога виникають уже в ранньому дитинстві, коли особистість тривалий час самотня, позбавлена батьківської ласки, веселих ігор і забав. Відсутність емоційно насиченої гри з батьками та однолітками не сприяє правильному емоційному реагуванню на стресові ситуації, збіднює емоційне життя 
дитини [13]. За спостереженнями О. Захарова, діти з високим рівнем тривожності схильні до певних страхів. Іноді прояви страху очевидні: розгубленість, заціпеніння, плач та жах. Про інші ж страхи можна говорити враховуючи непрямі ознаки: прагнення уникнути певних місць, розмов на певну тему, збентеження чи сором'язливість $[4$, с. 96$]$.

Більшість дітей проходять в своєму психічному розвитку ряд вікових періодів підвищеної чутливості до страхів. Особливість страхів дітей дошкільного віку полягає в тому, що на одному рівні існують страхи щодо вигаданих об'єктів (вампіри, темрява, привиди, жахи), тимчасові (тварини, комахи, змії) та глибинні (страх невідповідності, самотності, знехтування, відповідальності тощо) [13]. Дошкільний вік - період, коли в дитини починає формуватися мораль та образ власного «Я», виникає потреба осягнути явища суспільного життя, розібратися у взаєминах між людьми. Дитина так чи інакше потрапляє у світ нових емоцій і почуттів, стикається 3 життєвими ситуаціями, які часто не може пояснити, і як наслідок - виникнення страхів.

Можна виділити дві популярні точки зору на механізм виникнення страху. 3 точки зору біхевіоризму страх є наслідком одноразового чи багаторазового травматичного досвіду суб'єкта при взаємодії з певними об'єктами [6, с. 57]. Натомість у класичному психоаналізі першопричиною виникнення дитячих страхів вважають травму, яка пов'язана з відсутні- стю матері чи розлукою з нею [16, с. 39].

Страхи розглядаються як негативні емоційні стани дитини, пов'язані із відображенням у свідомості конкретної загрози емоційному благополуччю. Дитячі страхи проявляються в очікуванні та передбаченні дитиною невдачі при здійсненні конкретної дії. Якщо нормальний страх - це реакція на небезпеку, то невротичний страх можна кваліфікувати як виявлення лібідо. Таким чином можна виявити зв'язок між реальним і невротичним страхом через поняття небезпеки. Розвиток страху при неврозі виявляється результатом реакції «Я» на вимогу свого лібідо. Цю внутрішню небезпеку «Я» сприймає як зовнішню, і здійснює спробу втечі від свого лібідо. Таким чином «Я» використовуе симптом (наприклад, втечі у хворобу), який нівелює страх $[16$, с. 96]. Більшість дитячих страхів мають тимчасовий характер i, при своєчасному виявленні дорослими і правильному ставленні до них, незабаром безслідно зникають [13]. Натомість, невротичні або нав'язливі страхи, які ускладнюють нормальну життєдіяльність дитини, заважають ii розвитку та адаптації, поширюються на всі сфери життя.

Перші емоційні реакції, близькі за формою до почуття страху, виникають у дітей уже на першому році життя, наприклад, страх перед незнайомими людьми. Але здебільшого страхи починають зароджуватися в період адаптації до перебування в дошкільному закладі. На дитину впливає іiї вступ до дитсадка, 
що й призводить до виникнення неусвідомлених і невмотивованих страхів [7]. Діти можуть боятися вигаданих істот, лишатися самими удома, тварин, висоти, транспорту, лікарні, крові, уколів, фізичного та словесного покарання, темряви, незнайомих людей, страшних снів, дитсадка, стуку у двері, заходити в річку тощо. Проте вони ще не здатні усвідомлювати таке почуття як страх. Його розуміння з'являється лише в старшому дошкільному віці. Страх стає більш складним почуттям, набуває різних форм і видів. Урізноманітнюються об'єкти, що його викликають, розширюється сфера його проявів. Дитина соціалізується, починає орієнтуватися на громадську думку і як наслідок цього - боїться осуду колективу, відчуває страх бути не прийнятою у гру, страх самотності. Новоутворенням старшого дошкільного віку є також переживання страху за іншу людину (близьких дорослих, друзів тощо). Усвідомивши свій страх, дитина починає з ним боротися. Це, зрештою, зміцнює їі моральні основи, оскільки в соціальному розвитку страх є одним із засобів виховання [7, с.194].

До 5-6 років діти вчаться користуватися захисними механізмами, щоб приховувати чи маскувати свої почуття, і продовжують поводитись так ставши дорослими людьми. Найпоширеніші захисні механізми, які легко засвоюються дітьми, це утеча, ідентифікація, проекція, заміщення, заперечення, витіснення, регресія, реактивне утворення, раціоналізація, включення, відчуження [6, с. 235].
Захисним механізмом, що найчастіше проявляється в маленьких дітей, є утеча. Це самий простий захист із усіх можливих. Якщо ситуація здається занадто складною, дитина просто утікає від неї, фізично чи мисленнєво [2, с. 420]. Ідентифікація є інкорпоруванням цінностей, установок і поглядів інших людей. Діти переймають установки батьків, щоб стати схожими на них, тобто більш сильними, привабливими і визнаними. Цей механізм проявляється тоді, коли діти приписують власні недозволені думки чи вчинки комусь іншому і таким чином викривлюють дійсність. Проекція - захисний механізм, при використанні якого індивід приписує іншим свої власні неприйнятні бажання [16, с. 192]. Підміна справжнього джерела страху чи гніву чимось чи кимось іншим характеризує механізм заміщення. Коли дитині не вдається виконати дію, необхідну для досягнення певної цілі, вона іноді може робити будь-який безглуздий вчинок, що дає бодай якусь розрядку напруги. Відмова визнати, що якась ситуація або якісь події мають місце, характерне для механізму запереченням. Його сутність полягає в тому, що інформація, яка тривожить особистість і може призвести до конфлікту, не сприймається [2, с. 82]. Витіснення є несвідомим актом стирання лякаючої події чи обставини в тій частині пам'яті, до якої у людини є свідомий доступ. При певних обставинах дитина може повертатися до більш ранніх форм поведінки, які не відповідають їі віку. При цьому вона викорис- 
товує механізм регресії. У випадку застосування дітьми такого механізму як реактивне утворення, знижується рівень тривоги і страху шляхом пригнічення одних імпульсів та почуттів, і посилення імпульсів та почуттів протилежної модальності [8, с. 135]. Пояснення індивідом своїх бажань та вчинків, визнання яких загрожувало б втратою самоповаги, характерне для раціоналізації. Цей механізм дозволяє дитині знаходити виправдання своїм невдачам [8, с. 154]. Близьким до раціоналізації $\epsilon$ механізм включення, який також призводить до переоцінки значущості травмуючого чинника. Для цього використовується нова глобальна система цінностей, до якої попередня система входить як її частина. Прикладом захисту за типом включення може бути катарсис [8, c. 165]. Відчуження, або ізоляція, припускає відособлення усередині свідомості травмуючих факторів. При цьому доступ у свідомість неприємних емоцій блокується, що призводить до того, що зв'язок між певною подією та іiі емоційним забарвленням не відображається у свідомості [8, с. 170].

Більшість дошкільнят використовує декілька видів захисних механізмів. Утеча i заперечення характерні в основному для маленьких дітей. Захист за допомогою реактивного утворення передбачає більшу зрілість особистості. Деякі захисні механізми діти засвоюють спостерігаючи за поведінкою батьків чи найближчого оточення, але більшості видів захисної поведінки дитина навчається безпосередньо, пізнаючи на власному досвіді які з них краще допомагають впоратися із тривогою та страхом не викликаючи додаткових труднощів [6, с. 414]. Слід звернути увагу на те, що захисні механізми можуть бути корисними лише на протязі певного часу. Їх тривала дія призводить до гіперкомпенсації і появи труднощів, що ускладнюють розвиток особистості дитини, знижують активність ії життєвої позиції при досягненні соціально-значущих цілей $[2$, c. 35$]$.

Корекція страхів у дітей $є$ важливим завданням, оскільки страхи негативно впливають на формування особистості. Вона передбачає два етапи - визначення об'єкта страху, а потім перетворення його. Корекція страхів здійснюється за допомогою казкотерапії, ігротерапії, лялькотерапії, арт-терапії тощо. Також позитивний вплив мають індивідуальногрупові заняття і методи, які допомагають поліпшити взаєморозуміння між батьками та їхніми дітьми [6, с. 185].

С. Томчук вважає, що психопрофілактична робота щодо недопущення появи дитячих страхів повинна проводитись в таких напрямках: організація заходів безпосередньо для самих дітей (застосування бесід, ігрових форм роботи з розпізнання, самоаналізу та формування адекватних способів емоційного реагування); робота з батьками з метою профілактики негативних психічних станів у дітей (батьківський лекторій, індивідуальні та групові консультації, робота з батьками щодо оптимізації та гармонізації сімейного виховання); профілактичні, превентивні заходи серед 
вихователів (організація наукових, методичних семінарів з метою корекції деструктивних стилів педагогічного спілкування, навчання ефективним способам реагування в емоціогенних педагогічних ситуаціях, роботі з дітьми, які проявляють негативні психічні стани тощо). Психокорекційна робота може включати індивідуальну та групову форми взаємодії, психогімнастику, метод проективного малюнка, ліплення, методи десенсибілізації, позитивного підкріплення, елементи психологічного тренінгу, метод моделювання ситуацій, елементи музикотерапії. Найбільш ефективним на думку автора є використання психогімнастичних вправ на релаксацію, реагування, робота 3 проекціями, закріплення позитивних моделей поведінки [15].

За даними С. Томчука найбільш важливими завданнями роботи, спрямованими на корекцію дитячих страхів, є зняття стану тривоги та хвилювання, надмірного психоемоційного збудження, зміна ставлення до суб'єктивного джерела тривоги, научіння свідомо оцінювати та адекватним способом реагувати на ті чи інші внутрішньоособистісні проблеми та конфлікти, які часто і є причинами негативних психічних станів. Важливим є виділення за допомогою проективних методів особистісно значущих ситуацій, відносно яких у дитини знижений поріг чутливості до виникнення цілого ряду фрустраційних реакцій. 3 цією метою використовуються психомалюнки на різні теми, ліплення 3 пластичного матеріалу (глина, пластилін) тощо. Важливим завданням $\epsilon$ також корекція самооцінки дитини та рівня iï домагань, що сприяє децентрації дітей на своїх негараздах, труднощах та невдачах, зниженню фіксованості на своїх відчуттях, переживаннях та страхах. Для дітей слід створювати максимально позитивний емоційний фон, ситуації успіху (в реальних та ігрових умовах), самореалізації та самоствердження [15].

Попередження та подолання дитячих страхів є успішним через впровадження трьох напрямів роботи психолога: із педагогами (психокорекційна програма щодо подолання страхів повинна бути орієнтована на сумісну роботу педагога та психолога, одним із першочергових завдань психолога $€$ створення мотивації до включення у роботу саме педагога), сім'єю (отримання інформації від батьків про особливості розвитку дитини, зворотній зв'язок від батьків щодо ефективності проведеної психокорекційної роботи) та дітьми (психокорекційна програма має включати в себе ряд етапів, кожен із яких обумовлений особливостями адаптації дитини до взаємодії 3 соціальним оточенням) [6].

I. Бабарикіна виділяє такі завдання розвивально-корекційної роботи: формування мотивації участі у програмі, а також розвиток пізнавального інтересу дітей; розвиток умінь та якостей дітей, що сприятимуть успішному протистоянню та подоланню страхів; підвищення рівня обізнаності шкільного психолога та покращення його методичного забезпечен- 
ня [1].

О. Макух основними завданнями, спрямованими на корекцію дитячих страхів, вважає: розвиток уміння долати невротичні реагування, нормалізувати самопочуття, виховувати вольові якості та об'єктивне ставлення до ситуацій соціально-психологічного клімату; підвищення загальної комунікативної культури дітей; вдосконалення психологічних знань педагогів та батьків про закономірності психічного та соціального розвитку дітей; допомога батькам та педагогам в усвідомленні проблем, що виникають в окремої дитини; корекція стилю педагогічного спілкування та ставлення вчителів, батьків до труднощів, які виникають в процесі виховання та спілкування. Засобами корекції страхів є терапевтичні казки, моделювання ситуацій, ігри, малювання, ліплення, фрагменти музичної корекції, що забезпечують формування та розвиток комунікативних навичок, вербалізацію страхів та тривожності, усвідомлення особистих труднощів [10].

Психокорекція страхів в цілому розглядається як система роботи 3 виправлення окремих негативних проявів у діяльності та поведінці дитини, вад емоційно-вольової сфери, проблем у спілкуванні дитини з оточуючими їі людьми, відхилень у самооцінці, затримок у формуванні різних видів діяльності або в розвитку окремих психічних функцій, що в сукупності сприяє зниженню рівня переживання страхів. Завданням корекційної роботи є сприяння усвідомленню дітьми своїх страхів через їх об`єктивацію (в малюнках, текстах, інших виразних засобах); застосування методів релаксації, спрямованої уяви, заміни переживань страху на переживання успіху, переборення страху та знаходження задовільного виходу зі складних, „страшних” ситуацій з метою звільнення дитини від власних страхів; релаксаційна та терапевтична робота, спрямована на розвиток саморегуляції; формування вміння зосереджувати увагу на об'єктах та ситуаціях, що викликають страхи; переключення уваги на важливі та суттєві аспекти, переакцентування уваги, привернення уваги до себе; перехід від зовнішніх об'єктів до власних внутрішніх станів та трансформація цих станів в позитивному напрямі; підвищення ефективності взаємодії дітей $з$ педагогами, батьками, товаришами; формування ефективної комунікації [7].

Одним з методів корекції дитячих страхів $є$ казкотерапія. Це напрямок психотерапії, при якому для досягнення терапевтичного ефекту використовуються вигадані історії (казки). В дошкільному віці дитина вчиться думати про предмети і порівнювати їх подумки навіть тоді, коли вона їх не бачить. Дитина починає створювати моделі тієї дійсності, 3 якою має справу. Казка спонукає дитину співпереживати персонажам, у результаті чого у неї з'являються нові уявлення про людей, предмети і явища навколишнього світу, новий емоційний досвід. На цьому віковому етапі казка, певною мірою, задовольняє три природні потреби дитини: потребу в автономності, 
компетентності та активності [7, с. 78].

Для створення психокорекційної казки використовується такий алгоритм: підбір героя, близького дитині за статтю, віком, характером; опис життя героя у казковій країні так, щоб дитина помітила схожість зі своїм життям; перенос героя в проблемну ситуацію, схожу на реальну ситуацію дитини, і приписування герою всіх переживань дитини; пошук героєм казки виходу з проблемної ситуації; усвідомлення героєм казки своєї неоптимальної поведінки і визначення шляху для змін [7, c. 89].

При корекції страхів можна використовувати декілька варіантів роботи з казкою: розповідь казки (дає змогу виявити спонтанні емоційні прояви, які зазвичай не спостерігаються в поведінці дитини, але в той же час притаманні їй); малювання казки (допомагає дитині втілювати все, що ії хвилює, почуття та думки); казкотерапевтична діагностика (використання казок у процесі консультування дає змогу провести психодіагностичне обстеження дітей); твір-казка (дитина фантазує, створює казку, що дає можливість викиду негативних емоцій); постановка казки (допомагає розкрити емоції дитини, побачити iï поведінку в діяльності, рівень комунікативних навичок) [7, с. 103].

Також для корекції дитячих страхів ефективним $\epsilon$ застосування ігротерапії. В гуманістичній традиції ігрова терапія представлена клієнт-центрованим підходом. Виходячи
3 гуманістичного підходу, мета ігрової терапії полягає у створенні або відновленні значущих відносин між дитиною і дорослим з метою оптимізації особистісного зростання і розвитку. Гра як діяльність, вільна від примушення, підпорядкування, страху і залежності дитини від світу дорослих, і є місцем, де дитина має можливість вільного безперешкодного самовираження, дослідження і вивчення власних відчуттів і переживань. Гра дозволяє дитині звільнитися від емоційної напруженості і фрустрацій, обумовлених антагонізмом реальних життєвих стосунків між дитиною і дорослим. Інший підхід представлений ігровою терапією відреагування, центральним моментом якого виступає відтворення травмучої події, що дозволяє дитині звільнитися від болю і напруги, викликаних цією подією [3].

Можна виділити такі функції ігротерапії: діагностична - полягає в уточненні особливостей характеру дитини і міжособистісних стосунків; терапевтична - полягає в наданні дитині емоційного і моторного самовираження, відреагування напруги, страхів і фантазій, в процесі гри зміцнюються і розвиваються психічні процеси, підвищується фрустраційна толерантність і створюються адекватні форми психічного реагування; повчальна - полягає в перебудові відносин, розширенні діапазону спілкування і життєвого кругозору, реадаптації і соціалізації [3].

При корекції страхів використовується директивна і недирективна ігрова терапія. Ди- 
рективна ігрова терапія припускає виконання ігротерапевтом функцій інтерпретації і трансляції дитині символічного значення дитячої гри, активну участь дорослого в грі дитини 3 метою актуалізації в символічній ігровій формі несвідомих пригнічених тенденцій і їх програвання у напрямку соціально прийнятних стандартів і норм. Дитині пропонується декілька можливих варіантів вирішення проблеми. В результаті гри відбувається усвідомлення дитиною себе і своїх конфліктів. Натомість недирективна ігрова терапія спрямована на вільну гру як засіб самовираження дитини, що дозволяє одночасно успішно вирішити три важливих корекційних завдання: розширення репертуару самовираження дитини, досягнення емоційної стійкості і саморегуляції, корекція стосунків в системі «дитина - дорослий». На передній план виходять ідеї корекції страхів дитини шляхом формування адекватної системи стосунків між нею і дорослими та однолітками, системи конгруентної комунікації. Метою стає потреба допомогти дитині усвідомити саму себе, свої переваги і недоліки, труднощі і успіхи. Цей вид ігротерапії основується на таких принципах: дружні стосунки $з$ дитиною; безумовне прийняття дитини такою, якою вона є; відкритість і розкутість дитини; розуміння почуттів дитини. В процесі недирективної ігрової терапії відбувається організація емпатійного спілкування, забезпечення переживання дитиною відчуття власної гідності і самоповаги, встановлення обмежень в грі.
Дитина в процесі ігротерапії набуває важливого досвіду афектної сублімації в соціально прийнятних формах [3].

До структурованих ігор відносяться ігри в сім'ю (людей і тварин), агресивні, з маріонетками (ляльковий театр), будівельні, такі, що виражають конструктивні і деструктивні наміри. Структурований матеріал провокує вираз агресії, пряме вираження бажань, а також комунікативних дій (ігри в телефон, телеграф, потяги, машини). До неструктурованих ігор відносяться рухові ігри і вправи (стрибання, лазіння), ігри з водою, піском, глиною, група ігор, що належать до фонду арт -терапії (малювання пальцями, кистю, пастеллю, кольоровими олівцями). До неструктурованого матеріалу відноситься вода, пісок, глина, пластилін, 3 його допомогою дитина може висловлювати свої бажання. Цей матеріал сприяє також розвитку сублімації. Зокрема, заняття 3 неструктурованим матеріалом особливо важливі на ранніх фазах ігрової терапії, коли почуття дитини ще не виділені і не усвідомлені нею [3].

Ігрова терапія розглядається як засіб динамічної корекції розбалансованої емоційно-вольової сфери дошкільнят. Доцільність використання ігрової терапії при роботі зі страхами обумовлена, по-перше, тим, що гра для дітей є найбільш освоєним і органічним видом діяльності і спілкування, по-друге, тут представлена єдність психологічної природи гри і спілкування, по-третє, у грі дитина може 
вільно виражати себе, звільнитися від напруги. Нарешті, ігрова терапія представляє унікальний досвід для соціального і психологічного розвитку дитини [3].

Ще одним ефективним методом корекції дитячих страхів є арт-терапія. Вона характеризується: комплексом теоретичних, практичних ідей; взаємозв'язком із соціальними, психологічними й педагогічними явищами; відносною самостійністю від складових педагогічного процесу; здатністю до інтеграції та трансформації середовища. Функціями арттерапії з точки зору іiі застосування 3 дітьми дошкільного віку $є$ : аксіологічна, виховна, освітня, розвивальна, соціально-оздоровча. Так, виховна функція передбачає формування соціальних навичок, моральних та етичних цінностей, розвиток умінь діалогічної полікультурної взаємодії. Освітня роль полягає в набутті, поповнені та усвідомленні знань з етики, естетики, культурології, мистецтва. Соціально-оздоровча мета здійснюється за допомогою дотримання оптимального режиму психічних і фізичних навантажень, комфортного психологічного середовища, створення персоніфікованого виховного поля, набуття навичок творчої релаксації, попередження й подолання конфліктних ситуацій, збереження екології виховного середовища, розвитку адаптивних можливостей. Рекреативна функція розкривається в тому, що саме у творчості передбачається активна діяльність, яка дозволяє не лише поновити, але й розвинути життєві сили дитини - інтелектуальні, емоційні, духовні. Під час організації арт-терапевтичного процесу необхідно враховувати принцип діяльнісної корекції, який означає, що генеральним способом арт-терапевтичних заходів $є$ організація активної діяльності дитини, у ході якої створюються умови для іiї орієнтирів у конфліктних ситуаціях, організовується необхідна основа для позитивних змін [9].

Висновки. Аналіз уявлень вітчизняних та зарубіжних дослідників щодо піднятої проблеми показав, що страх визначається як реакція на конкретну зовнішню загрозу, як інстинкт, фундаментальна емоція, психічний стан, конкретизована тривога, сигнал про небезпеку. Страх завжди спрямований на об'єкт, а тривога може виникати незалежно від стимулу. Тривога - реакція на уявну, неіснуючу загрозу, а страх - на конкретну. Страх як комплексне утворення включає фізіологічні, поведінкові та когнітивні прояви і може бути визначений як негативний емоційний стан, який пов'язаний із відображенням у свідомості конкретної загрози для життя та благополуччя індивіда, що проявляється в очікуванні і передбаченні небезпеки. Дошкільний вік є сенситивним періодом для виникнення страхів, що можуть набувати різних видів та форм. Це передбачає включення механізмів психологічного захисту, найпоширенішими 3 яких в цей віковий період є втеча і заперечення. Корекційна діяльність, спрямована на подолання актуалізованих страхів, передбачає застосу- 
вання психологічного супроводу та роботу не лише 3 дитиною, але й з їі найближчим оточенням.

\section{Перспективним напрямком дослі-} дження $є$ здійснення подальшого аналізу психологічних особливостей появи та актуалізації страхів в дошкільному віці з метою розробки ефективних засобів їх профілактики та корекцiï.

\section{Перелік використаних джерел:}

1. Бабарикіна I. В. Психологічні особливості вікової динаміки страхів у навчальній діяльності школярів: автореф. дис. ... канд. психол. наук : 19.00.07 / I. В. Бабарикіна ; Харк. нац. пед. ун-т ім. Г.С. Сковороди. - Х., 2011. $-20 \mathrm{c}$.

2. Большой толковый психологический словар / Пер. с англ. Укл. А. Ребер. - М. : Вече, 2000. - 592 с.

3. Васильченко O. А. Ігрова терапія як метод соціальної роботи $з$ дітьми шкільного віку / О.А. Васильченко // Вісник НТУУ «КПІ». Політологія. Соціологія. Право, 2013. - Вип. 3 (19). - С. 44-48.

4. Захаров А. И. Дневные и ночные страхи у детей / А. И. Захаров. - СПб.: Питер, 2000. - 448 с.

5. Изард К. Э. Психология эмоций / К. Э. Изард.-- СПб.: Питер, 2012. - 464 с.

6. Кляйн М. Детский психоаналіз / М. Кляйн. - СПб.: Институт общегуманитарных исследований, 2010. $160 \mathrm{c}$.

7. Кузнєцов М. А. Шкільні страхи: види, умови прояву та шляхи подолання: монографія / М. А. Кузнєцов, І. В. Бабарикіна; Харк. нац. пед. ун-т ім. Г.С. Сковороди. Х. : ХНПУ, 2012. - 227 c.

8. Литвак М. Если хочешь быть счастливым / М. Литвак. - Ростов-на-Дону: Феникс, 1995. - 295 с.

9. Литвиненко В. Теоретичні підходи до організації арттерапевтичного процесу в системі оздоровчо- фізкультурної роботи з дітьми дошкільного віку / В. Литвиненко, Н. Кукса // Педагогічні науки: теорія, історія, інноваційні технології, 2016. - № 3 (57). С. 22-27.

10. Макух О. I. Особливості межових психічних станів молодших школярів у процесі навчальної діяльності: автореф. дис. ... канд. психол. наук: 19.00.07 / О. І. Макух ; Ін-т психології ім. Г.С. Костюка АПН України. K., 2009. -20 c.

11. Мовчан М. М. Дитячі страхи як особливий різновид людських страхів / М. М. Мовчан // Науковий часопис Національного педагогічного університету ім.. М.П. Драгоманова: Зб. наук. праць. - К. : НПУ ім. М. П. Драгоманова, 2013. - Вип. 29 (42). - С. 210-218.

12. Морозюк B. М. Корекція дитячих страхів, як напрямок роботи практичних психологів / В. М. Морозюк // Науковий часопис Національного педагогічного університету ім. М.П. Драгоманова. - К. : НПУ, 2007. - Вип. 19 (43). - С. 184-188.

13. Поддубная Н. Я. Страхи и тревожность как деструктивные эмоциональные состояния в жизни младшего школьника: теоретический аспект проблемы / Н. Г. Поддубная, О.В.Большунова // Состояние здоровья: медицинские, социальные и психолого-педагогические аспекты. - Чита, 2013. - С. 154-160.

14. Стукан Л. В. Причини, умови, механізми формування соціальних фобій у підлітків, їх психокорекція та психопрофілактика: автореф. дис... канд. мед. наук: 19.00.04 / Л. В. Стукан ; Харк. мед. акад. післядиплом. освіти. - Х., 2006. - 20 с.

15. Томчук C. М. Генеза негативних психічних станів молодших школярів та їх корекція: автореф. дис... канд. психол. наук: 19.00.07 / С.М. Томчук ; Нац. пед. ун-т ім. М.П. Драгоманова. - К., 2006. - 20 с.

16. Фрейд 3. Психоанализ детских страхов / З.Фрейд. СПб.: Азбука, 2016. - 288 с.

\section{References (Transliteration):}

1. Babarikina I. V. Psihologichni osoblivosti vikovoyi dinamiki strahiv u navchalniy dIyalnosti shkolyariv: 
avtoref. dis. ... kand. psihol. nauk : 19.00 .07 / I. V. BabarikIna ; Hark. nats. ped. un-t Im. G.S. Skovorodi. - H., 2011. $-20 \mathrm{~s}$.

2. Bolshoy tolkovyiy psihologicheskiy slovar / Per. s angl. Ukl. A. Reber. - M. : Veche, 2000. - 592 s.

3. Vasilchenko $O$. A. Igrova terapiya yak metod sotsialnoyi roboti z ditmi shkIlnogo viku / O.A. Vasilchenko // Visnik NTUU «KPI». Politologiya. Sotsiologiya. Pravo, 2013. Vip. 3 (19). - S. 44-48.

4. Zaharov A. I. Dnevnyie i nochnyie strahi u detey / A. I. Zaharov. - SPb.: Piter, 2000. - 448 s.

5. Izard K. E. Psihologiya emotsiy / K. E. Izard. $\neg-\mathrm{SPb}$.: Piter, 2012. $-464 \mathrm{~s}$.

6. Klyayn M. Detskiy psihoanaliz / M. Klyayn. - SPb.: Institut obschegumanitarnyih issledovaniy, 2010. - 160s.

7. Kuznetsov M. A. Shkilni strahi: vidi, umovi proyavu ta shlyahi podolannya: monografIya / M. A. KuznEtsov, I. V. BabarikIna; Hark. nats. ped. un-t Im. G.S. Skovorodi. - H. : HNPU, 2012. - 227 c.

8. Litvak M. Esli hochesh byit schastlivyim / M. Litvak. Rostov-na-Donu: Feniks, 1995. - 295 s.

9. Litvinenko $V$. TeoretichnI pidhodi do organIzatsiyi artterapevtichnogo protsesu $\mathrm{v}$ sistemI ozdorovchofIzkulturnoYi roboti $\mathrm{z}$ dItmi doshkIlnogo vIku / V. Litvinenko, N. Kuksa // PedagogIchnI nauki: teorIya, IstorIya, InnovatsIynI tehnologIYi, 2016. - \# 3 (57). S. 2227.

10. Makuh O. I. Osoblivosti mezhovih psihichnih staniv molodshih shkolyariv $\mathrm{u}$ protsesi navchalnoyi dIyalnosti: avtoref. dis. ... kand. psihol. nauk: 19.00.07 / O. I. Makuh ; In-t psihologiyi Im. G.S. Kostyuka APN Ukrayini. - K., 2009. $-20 \mathrm{~s}$.

11. Movchan M. M. Dityachi strahi yak osobliviy rIznovid lyudskih strahIv / M. M. Movchan // Naukoviy chasopis NatsIonalnogo pedagogIchnogo unIversitetu Im.. M.P. Dragomanova: Zb. nauk. prats. - K. : NPU Im. M. P. Dragomanova, 2013. - Vip. 29 (42). - S. 210-218.

12. Morozyuk V. M. Korektsiya dityachih strahiv, yak napryamok roboti praktichnih psihologIv / V. M. Morozyuk // Naukoviy chasopis NatsIonalnogo
pedagogIchnogo unIversitetu Im. M.P. Dragomanova. - K.: NPU, 2007. - Vip. 19 (43). - S. 184-188.

13. Poddubnaya N. Ya. Strahi i trevozhnost kak destruktivnyie emotsionalnyie sostoyaniya $\mathrm{V}$ zhizni mladshego shkolnika: teoreticheskiy aspekt problemyi / N. G. Poddubnaya, O. V. Bolshunova // Sostoyanie zdorovya: meditsinskie, sotsialnyie i psihologo-pedagogicheskie aspektyi. - Chita, 2013. - C. 154-160.

14. Stukan L. V. Prichini, umovi, mehanIzmi formuvannya sotsIalnih fobIy $\mathrm{u}$ pIdlItkIv, Yih psihokorektsIya ta psihoprofIlaktika: avtoref. dis... kand. med. nauk: 19.00.04 / L. V. Stukan ; Hark. med. akad. pIslyadiplom. osvIti. - H., 2006. - $20 \mathrm{~s}$.

15. Tomchuk $S$. M. Geneza negativnih psihIchnih stanIv molodshih shkolyarIv ta Yih korektsIya: avtoref. dis... kand. psihol. nauk: 19.00.07 / S.M. Tomchuk ; Nats. ped. un-t Im. M.P. Dragomanova. - K., 2006. - 20 s.

16. Freyd Z. Psihoanaliz detskih strahov / Z.Freyd. - SPb.: Azbuka, 2016. - 288 s.

\section{Kaminska Olga}

Doctor of Psychology, Associate Professor, Professor of the Department of General Psychology and Psychodiagnostics, Rivne State Humanitarian University, Rivne (Ukraine)

\section{Hromyk Nataliia}

Master's Degree Student, Rivne State Humanitarian University, Rivne (Ukraine)

\section{CHILDHOOD FEARS PROBLEM IN WORKS OF NATIONAL AND INTERNATIONAL RESEARCHERS}

\section{ABSTRACT}

It was emphasized that the relevance of the study has been caused by its major role in child's life. The fear might exist on a conscious level of personality as well as on a subconscious 
one having impact on all aspects of life. When the fear becomes a phobia it is able to decrease the quantity of an individual's life, bounds one's vital activity and social cooperation, negatively affects socialization development, which is very important in a preschool age. Accordingly, the fear actualization, its compulsive nature, disturbs the child's personality formation process, causes destructive changes in the communication with adults and children of the same age. It also may cause a misperception of substantive environment depending on the object of fear. Theoretical analysis of "fear" conception has been accomplished; its nature has been determined by different approaches in psychology. The views of national and international scientists regarding the fear problem have been presented. Scientists' points of view on the fear and anxiety differentiation have been enlightened. The place of "fear" conception in psychological categories has been determined. Special aspects of fear origin among the children of preschool age have been analyzed. Most common kinds of fear among children have been determined as well as the stages of their transitions into phobias. The influence of child's surrounding community on the creation of obsessive fears has been displayed. Ways and forms of preschool age children's fear correction have been pointed. The psychological defense mechanisms' role in a leveling of child's own fears has been discovered. The necessity of psychological support service for children who struggle from obsessive fears and phobias have been brought into focus. It is discovered that the fear is determined as a reaction to the specific outer menace, instinct, a fundamental emotion, a mental state, an elaborated anxiety and danger signal. The fear is always directed toward the object and the anxiety might appear regardless of the motive. The anxiety is a reaction to imaginary, non-existent danger, but the fear - on a contrary - is a reaction to concrete one. As a compound structure, the fear itself includes physiological, behavioral and cognitive aspects and can be determined as a negative emotional state, which is connected to the reflection of a certain danger for individual's life and prosperity in consciousness. It appears in anticipation and prediction of a danger. It is underlined that the preschool age is a sensitive period for fear uprising, which can take on vary types and forms. It includes psychological defense mechanisms switching-on such as runaway and denial which are widespread among the children of this age. It is proved that the corrective work, which is focused on actualized fears overcoming, provides for the use of psychological support not only for a child, but for immediate environment also.

Key words: fear, phobia, anxiety, emotions, preschool age.

() Камінська О. В., Громик Н. В. 


\section{Каминская Ольга Владимировна}

Доктор психологических наук, доцент, профессор кафедры общей психологии и психодиагностики, Ровенский государственнылй гуманитарнылй университет, Ровно (Украина)

\section{Громик Наталья Васильевна}

Магистрант, Ровенский государственньй гуманитарный университет, Ровно (Украина)

\section{ПРОБЛЕМА ДЕТСКИХ СТРАХОВ В ИССЛЕДОВАНИЯХ ОТЕЧЕСТВЕННЫХ И ЗАРУБЕЖНЫХ УЧЕНЫХ}

Аннотация. Подчеркнуто, что актуальность исследования проблемы страха обусловлена его значительной ролью в жизни ребенка. Страх может присутствовать как на уровне сознания, так и на уровне подсознания личности, воздействуя на различные сферы ее жизни. Страх, который функционирует на уровне фобии, способен в значительной степени снижать качество жизни личности, ограничивая ее жизнедеятельность, социальное взаимодействие и негативно влиять на процесс социализации, который является особенно важным в дошкольном возрасте. Соответственно, актуализация страха, его навязчивый характер, нарушает процесс становления личности ребенка, приводит к деструктивным изменениям в его взаимодействии со взрослыми, сверстниками, или вызывает искаженное восприятие предметной среды, в зависимости от объекта, на который направлено чувство страха. Осуществлен теоретический анализ понятия «страх», определены его сущность с точки зрения различных психологических течений. Приведены взгляды отечественных и зарубежных ученых на проблему страха. Приведены мнения ученых по поводу разграничения понятий «страх» и «тревога». Определено место понятия «страх» в системе психологических категорий. Проанализированы особенности возникновения страхов у детей дошкольного возраста. Определены преобладающие виды детских страхов и условия перехода страхов в фобии. Показано влияние ближайшего окружения ребенка на возникновение у него навязчивых страхов. Указаны средства и формы коррекции страхов у детей дошкольного возраста. Проанализирована роль механизмов психологической защиты в нивелировании ребенком собственных страхов. Подчеркнута необходимость оказания психологической помощи детям, у которых наблюдаются навязчивые страхи и фобии. Установлено, что страх определяется как реакция на конкретную внешнюю угрозу, как инстинкт, фундаментальная эмоция, психическое состояние, конкретизированая тревога, сигнал об опасности. Страх всегда направлен на объект, а тревога может возникать независимо от стимула. Тревога - реакция на кажущуюся, несуществующую угрозу, а страх - на конкретную. Страх как комплексное образование включает физиологические, поведенческие и когнитивные проявления и может быть определен как отрицательное эмоциональное состояние, которое связано с отражением в сознании конкретной 
угрозы для жизни и благополучия индивида и проявляется в ожидании и предвидении опасности. Подчеркнуто, что дошкольный возраст является сенситивным периодом для возникновения страхов, которые могут принимать различные виды и формы. Это предполагает включение механизмов психологической защиты, наиболее распространенными из которых в этот возрастной период является бегство и отрицание. Доказано, что коррекционная деятельность, направленная на преодоление актуализированных страхов, предусматривает применение психологического сопровождения и работу не только с ребенком, но и с его ближайшим окружением.

Ключевые слова: страх, фобия, тревожность, эмоции, дошкольный возраст. 